\title{
Citrus Longhorned Beetle, Anoplophora chinensis (Forster) (Insecta: Coleoptera: Cerambycidae) ${ }^{1}$
}

Jamba Gyeltshen and Amanda Hodges ${ }^{2}$

\section{Introduction}

The citrus longhorned beetle (CLHB), Anoplophora chinenis (Forster), is a serious pest of citrus in China but did not occur in the U.S. until it was detected in a Washington nursery in 2001. An eradication program was immediately implemented in Washington and there have subsequently been no new infestation reports (Anonymous 2005). However, with the increasing global trade and movement of plant materials, there is an imminent risk of establishment of CLHB in new areas.

With a host range of more than 40 hardwood species, CLHB is a potential threat to natural areas as well as fruit trees and woody ornamental plants (Anonymous 2002b). Unlike many other native borer pests that primarily attack dead trees, CLHB attacks apparently healthy trees (Chambers 2002). Once established, it can be extremely difficult and expensive to eradicate. A closely related species, the Asian longhorned beetle, Anoplophora glabripennis (Motschulsky) caused the destruction of thousands of trees in New York and Chicago and cost \$369 million for eradication efforts (Anonymous 2005).

\section{Synonymy}

The genus Anoplophora was most recently revised by Lingafelter and Hoebeke (2002). The authors synonymized Anoplophora malasiaca (Thomson) with Anoplophora chinensis. The following are other scientific names used for Anoplophora chinensis by earlier workers (Lingafelter and Hoebeke 2002, CABI 2004).

- Melanauster chinensis Thomson

- Melanauster perroudi Pic 1953

- Anoplophora sepulchralis Breuning 1944

- Calloplophora sepulcralis Thomson 1865

- Calloplophora malasiaca Thomson 1865

- Calloplophora afflicta Thomson 1865

- Calloplophora luctuosa Thomson 1865

- Calloplophora abbreviata Thomson 1865

- Cerambyx sinensis Gmelin 1790

1. This document is EENY-357, one of a series of Featured Creatures from the Entomology and Nematology Department, Florida Cooperative Extension Service, Institute of Food and Agricultural Sciences, University of Florida. Published: September 2005. This document is also available on Featured Creatures Website at http://creatures.ifas.ufl.edu. Please visit the EDIS Website at http://edis.ifas.ufl.edu.

2. Jamba Gyeltshen and Amanda Hodges, University of Florida, Gainesville, FL.

The Institute of Food and Agricultural Sciences (IFAS) is an Equal Opportunity Institution authorized to provide research, educational information and other services only to individuals and institutions that function with non-discrimination with respect to race, creed, color, religion, age, disability, sex, sexual orientation, marital status, national origin, political opinions or affiliations. U.S. Department of Agriculture, Cooperative Extension Service, University of Florida, IFAS, Florida A. \& M. University Cooperative Extension Program, and Boards of County Commissioners Cooperating. Larry Arrington, Dean 
- Cerambyx pulchricornis Voet 1778

- Lamia punctator Fabricius 1777

- Cerambyx chinensis Forster 1771

- Cerambyx farinosus Houttuyn 1766

\section{Distribution}

CLHB primarily occurs in China, Korea, and Japan but it is also found in Taiwan, the Philippines, Indonesia, Malaysia, Myanmar, and Vietnam (CABI 2004). In North America, except for interceptions at various ports of entry, there were no records of established populations until local infestations were detected for the first time in Tukwila, Washington on maple trees (Acer) imported from Korea (Grob 2003, Lingafelter and Hoebeke 2002). Since then, eradication measures were taken and quarantine regulations imposed. As of 2005 there were no reports of new infestation (2005 Updates).

Prior to the localized Washington population, a single adult CLHB was intercepted in 1999 at a nursery in Athens, Georgia, on a shipment of crepe myrtle (Lagerstroemia) bonsai from China (Thomas 2004).

\section{Description}

Adult: The beetle is large, stout, and approximately 21 to $37 \mathrm{~mm}(\sim 1-1.5 \mathrm{inch})$ long with shiny black elytra marked with 10 to 12 white round spots (Lingafelter and Hoebeke 2002). Males are generally smaller than females, and have their abdomen tip entirely covered by the elytra, in contrast to the partially exposed abdomen of females (Lieu 1945). Also, the male elytra are narrowed distally compared to the rounded female elytra. Another difference between males and females is antennal size. The male's antennae are approximately twice as long as the body when compared to the female's antennae which are only slightly longer than the body. Each segment of the long, 11-segmented antennae is basally marked with white or light blue bands. The anteriorly and posteriorly narrowed pronotum has a pair of stout spines extending from its sides.

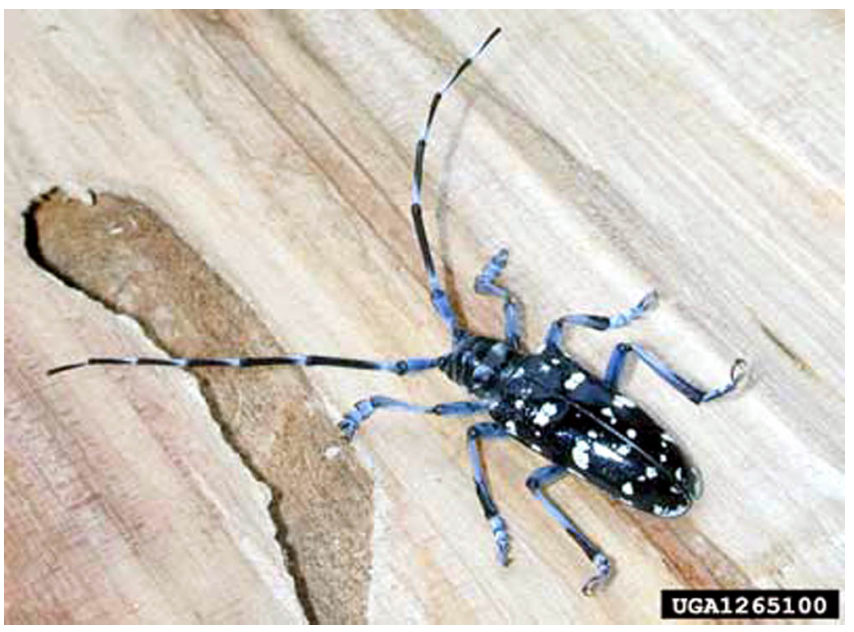

Figure 1. Adult citrus longhorned beetle, Anoplophora chinensis (Forster). Credits: Washington State Department of Agriculture Archives; www.forestryimages.org

The base of the elytra has numerous short processes (tubercles) called granulae, a morphological character that may help to differentiate CLHB from the Asian longhorned beetle, Anoplophora glabripennis.

Egg: The egg is $5.5 \mathrm{~mm}$ ( $0.22 \mathrm{inch})$ long and 1.7 $\mathrm{mm}$ (0.07 inch) wide, elongate, sub-cylindrical, smooth-surfaced, and tapering at both ends; it is initially creamy white but gradually turns yellowish brown when ready to hatch (Lieu 1945).

Larva: The legless larva, which is $5 \mathrm{~mm}(0.2$ inch) long at the time of hatching, grows to a size of $52 \mathrm{~mm}$ (2 inch). It is creamy white with some yellow, chitinized patterns on the prothorax.

Pupa: The pupa is 27 to $38 \mathrm{~mm}$ ( 1 to 1.5 inch) long; it has elytra that only partially covers the membranous hind wings and curves around to the ventral surface of the body.

\section{Life Cycle}

In China, CLHB is known to emerge from April to August but is most abundant from May to July (CABI 2004). Soon after emergence, the adult feeds on leaves, petioles, and bark of twigs of preferred host plants. Most activity, including feeding and mating, occur during the day. Eggs are deposited under the bark through a T-shaped oviposition slit made at the base of the trunk or exposed roots. Under rearing conditions, Lieu (1945) observed an average fecundity of 15 eggs, but some sources mention that a 
single female is capable of laying as many as 200 eggs (Anonymous 2002b).

The young larva hatches out in one to three weeks and initially feed on the green, sappy portion of the inner bark. During its later instars, the larva makes irregular tunnels in the wood, and continue to do so until pupation. The pupal stage lasts for four to six weeks until a pre-adult is formed with the final molt. The pre-adult is inactive and takes about one to two weeks to mature and emerge out of the tunnel. CLHB takes approximately one year to complete its development (CABI 2004, Lieu 1945).

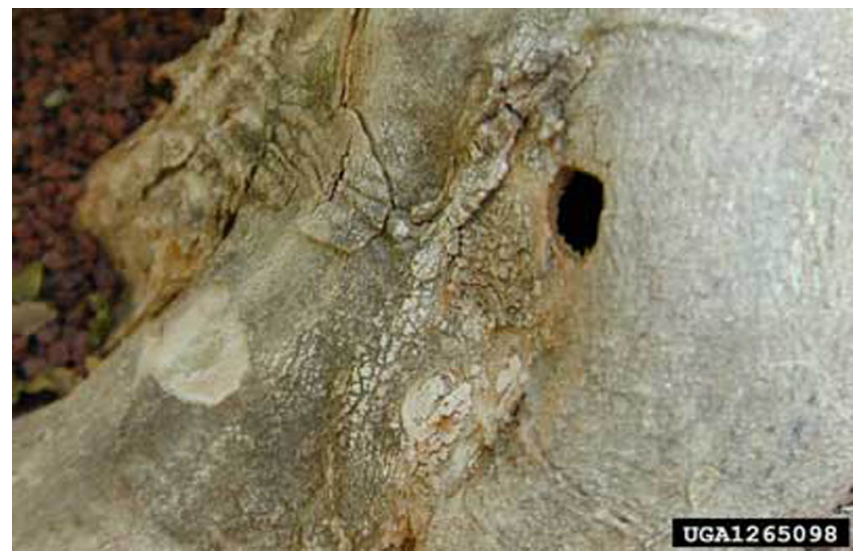

Figure 2. Exit hole created by the emergence of an adult citrus longhorned beetle, Anoplophora chinensis (Forster). Credits: Washington State Department of Agriculture Archives; www.forestryimages.org

\section{Host Plants}

The citrus longhorned beetle is a polyphagous pest attacking living trees of over 100 species. It is a pest of major concern for citrus growers in parts of China. Its primary hosts include, lime/lemon/oranges/tangor (Citrus), trifoliate orange (Poncirus trifoliata), apple (Malus pumila), Australian pine (Casuarina equisetifolia), poplars (Populus), and willows (Salix) (CABI 2004). However, it attacks a wide range of trees and shrubs in 26 different families and more than 40 genera.

The Washington State Department of Agriculture declared the following genera (species) of plants as potential hosts for CLHB (Anonymous 2002a): maples (Acer), silk tree (Albizzia), alders (Alnus), birch (Betula), Camellia, hickory/pecan (Carya), chestnut (Castanea), Japanese cedar (Cryptomeria), wild olive (Elaeagnus), loquat (Eriobotrya japonica), beech (Fagus), fig (Ficus),
'Nagami' kumquat (Fortunella marginata), ash (Fraxinus), mallow (Hibiscus), holly (Ilex), walnut (Juglans), spicebush (Lindera), amur (Maackia), mulberry (Morus), Photinia, sycamore/plane tree (Platanus), trifoliate orange (Poncirus trifoliata), poplars (Populus), cherry/peach/apricot/plum (Prunus), firethorn (Pyracantha), pears (Pyrus), oaks (Quercus), sumac (Rhus), locust (Robinia), rose (Rosa), blackberry/raspberry (Rubus), willows (Salix), pagoda tee (Sophora), Stransvaesia, snowbell tree (Styrax), and elm (Ulmus).

\section{Damage}

The majority of damage associated with CLHB is caused by the larval stages which feeds and tunnel on the woody portion of the host plant trunk. The wounds created during the course of feeding increase the host susceptibility to various secondary plant pathogens. Later instar larvae have stronger mouthparts and are able to burrow deep into the wood and create irregular tunnels that interfere with the water and nutrient transportation resulting in rapid tree decline. As compared to the younger trees, older trees with larger trunk diameters are able to sustain more damage. Although adults do feed on leaves, and bark of twigs, the damage is usually not considered severe.

\section{Management}

Natural control. CLHB larvae are most susceptible to natural enemies in the early larval instar stage, or approximately the first two months of development. In China, predation by the weaver/red ants, Oecophylla smaragdina (Fab.) prevented the need for chemical control (Lieu 1945, Yang 1984).

Sanitation. Field sanitation including cutting and burning/chipping of infested plant parts can eliminate immature stages.

Mechanical exclusion. Since eggs are laid under the bark at the base of the trunk, wire nettings or spiral guards at the trunk base can serve as physical barrier for female oviposition.

Biological control. The pathogenic fungi Beauveria brongniartii (Sacc.) is known to cause high adult mortality. In Japan, studies demonstrated 
adult mortality of 46 to $100 \%$ when sheets of polyurethane forms impregnated with Beauveria brongniartii were wrapped around the lower portion of the trunk or hung from the crotch (CABI 2004).

Chemical control. Systemic insecticides are injected into base of a tree from where it is circulated to the branches, twigs and foliage. The tree injection has been a successful component of the Asian longhorned beetle eradication program and imidacloprid was recommended for use during the eradication program for CLHB (WSDA 2002, Anonymous 2002b). Both adults and larvae are exposed to insecticides when treated by tree injection.

Reporting. An integrated approach including extensive surveys, surveillance, tree removal, chemical treatment, and regulated movement of potential host plant species out of the quarantine areas is required for a successful CLHB eradication program. Since CLHB is a regulated pest, any suspect sample should be sent to your local State Department of Agriculture or USDA-APHIS for advice and action. Your local Cooperative Extension Service can also assist you with identification questions. In Florida, specimens should be submitted to the Division of Plant Industry (Thomas 2004).

\section{Selected References}

Anonymous. (2002a). Longhorned Beetle Quarantine Language (adopted April 17, 2002). Washington State Department of Agriculture. http://agr.wa.gov/PlantsInsects/InsectPests/CLHB/ docs/Tukwila/QuarantineLanguage.pdf (3 March 2005).

Anonymous. (2002b). Washington's tree slayer: The citrus longhorned beetle. Citrus longhorned beetle eradication project. Washington State Department of Agriculture. http://agr.wa.gov/ PlantsInsects/InsectPests/CLHB/docs/Tukwila/ TreeSlayer_final.pdf (20 March 2005).

Anonymous. (2005). Citrus longhorned beetles found in Tukwila. http://www.ci.tukwila.wa.us/ beetle.htm (12 June 2005).

CABI. (2004). Crop Protection Compendium. http://www.cabicompendium.org/ (9 June 2005).
Chambers B. (2002). Citrus longhorned beetle program, King County, Washington: Environmental Assessment, April 2002. http://www.aphis.usda.gov/ ppd/es/pdf files/clb.pdf (20 March 2005).

Grob JA. (2003). The beetle battle. http://www. sciam.com/article.cfm?articleID $=0000260 \mathrm{C}-5 \mathrm{~A} 10$ 1E56-A98A809EC5880105\&sc $=I 100322(26$ January 2005).

Lieu KOV. 1945. The study of wood borers in China -- I: Biology and control of the citrus-root-cerambycids, Melanauster chinensis, Forster (Coleoptera). The Florida Entomologist 27:61-101.

Lingafelter SW, Hoebeke ER. 2002. Revision of Anoplophora (Coleoptera: Cerambycidae). Entomological Society of Washington, Washington, DC. $236 \mathrm{pp}$.

Thomas MC. (2004). Citrus Longhorned Beetle (CLB), Anoplophora chinensis (Forester). FDACS-DPI Pest Alert. http://www.doacs.state.fl. us/pi/enpp/ento/clbalert.htm (12 September 2005).

WSDA. (2002). Citrus longhorned beetle eradication project: Tree injection: Another weapon against the Citrus longhorned beetle. http://agr.wa. gov/PlantsInsects/InsectPests/CLHB/docs/Tukwila/ InjectionFAQFinal.pdf (26 August 2005).

Yang P. 1984. The application of Oecophylla smaragdina Fabr. in South Fujian. Fujian Agricultural Science and Technology, No. 5:23-25 (CAB abstracts). 